\title{
Complex Assessment of Metabolic Effectiveness of Insulin Pump Therapy in Patients with Type 2 Diabetes Beyond HbA1c Reduction
}

\author{
Rudolf Chlup, MD, ${ }^{1-3}$ Sarah Runzis, MSc, Javier Castaneda, MSc, Scott W. Lee, MD, \\ Xuan Nguyen, and Ohad Cohen, $\mathrm{MD}^{7}$
}

\begin{abstract}
Background: This prospective single-center study recruited insulin-resistant continuous subcutaneous insulin infusion (CSII) therapy-naive patients with type 2 diabetes (T2D) using insulin analog-based multiple daily injections (MDI) therapy and metformin.

Methods: A total of 23 individuals with T2D (70\% male), aged a mean \pm standard deviation $57.2 \pm 8.03$ years, with body mass index of $36.2 \pm 7.02 \mathrm{~kg} / \mathrm{m}^{2}$, diabetes duration of $13.3 \pm 4.64$ years, and $\mathrm{HbA} 1 \mathrm{c}$ of $10.0 \% \pm 1.05 \%$ were randomly assigned to a CSII arm or an MDI continuation arm to explore glucose control, weight loss, total daily insulin dose (TDD), and insulin resistance. Insulin dosing was optimized over a 2-month run-in period.

Results: At 6 months, patients assigned to the CSII arm achieved a significant mean HbA1c reduction of $-0.9 \%$ (95\% confidence interval $[\mathrm{CI}]=-1.6,-0.1)$, while reducing their TDD by $-29.8 \pm 28.41 \mathrm{U} /$ day $(33 \%$ of baseline [92.1 $\pm 20.35 \mathrm{U} /$ day] $)$ and achieving body mass $(\mathrm{BM})$ reduction of $-0.8 \pm 5.61 \mathrm{~kg}(0.98 \%$ of baseline [104.8 $\pm 16.15 \mathrm{~kg}])$. MDI patients demonstrated a nonsignificant $\mathrm{HbA} 1 \mathrm{c}$ reduction of $-0.3 \%(95 \%$ $\mathrm{CI}=-0.8,0.1)$ with a TDD reduction of $5 \%$ from baseline $(99.0 \pm 25.25 \mathrm{U} /$ day to $94.3 \pm 21.25 \mathrm{U} / \mathrm{day})$, and a $\mathrm{BM}$ reduction of $-1.0 \pm 2.03 \mathrm{~kg}(0.99 \%$ of baseline [108.9 $\pm 20.55 \mathrm{~kg}])$. After 6 months, the MDI arm crossed over to CSII therapy. At 12 months, patients continuing CSII demonstrated an additional mean $0.7 \% \mathrm{HbA} 1 \mathrm{c}$ reduction with $54.6 \%$ achieving $\mathrm{HbA} 1 \mathrm{c}<8 \%$. The final TDD reduction was $-9.7 \mathrm{U} /$ day in comparison to baseline; $\mathrm{BM}$ increased by $1.1 \pm 6.5 \mathrm{~kg}$ from baseline. The MDI patients that crossed to CSII showed an $\mathrm{HbA} 1 \mathrm{c}$ reduction of $-0.5 \% \pm 1.04 \%$, HbA1c response rate of $27.3 \%$, a TDD reduction of $-17.4 \pm 21.06 \mathrm{U} /$ day, and a BM reduction of $-0.3 \pm 3.39 \mathrm{~kg}$. Diabetic ketoacidosis or severe hypoglycemia did not occur in either arm. Conclusion: CSII therapy safely and significantly improved metabolic control with less insulin usage, with no sustainable reduction of $\mathrm{BM}$, blood pressure, and lipid profile, in insulin-resistant T2D patients. Treatment adherence and satisfaction in these patients were excellent.
\end{abstract}

Keywords: Insulin pump, Type 2 diabetes, Insulin aspart, HbA1c, Body mass, Self-monitoring.

\footnotetext{
${ }^{1}$ Department of Physiology, Faculty of Medicine and Dentistry, Palacký University, Olomouc, Czech Republic.

${ }^{2}$ IInd Department of Medicine, Teaching Hospital, Olomouc, Czech Republic.

${ }^{3}$ Department of Diabetes Moravsky Beroun, Institute Paseka, Paseka, Czech Republic.

${ }^{4}$ Medtronic, Sarl, Tolochenaz, Switzerland.

${ }^{5}$ Medtronic, Bakken Research Center, Maastricht, The Netherlands.

${ }^{6}$ Medtronic, Northridge, California.

${ }^{7}$ Medtronic, Tolochenaz, Switzerland.
}

(C) Rudolf Chlup, et al., 2018; Published by Mary Ann Liebert, Inc. This Open Access article is distributed under the terms of the Creative Commons License (http://creativecommons.org/licenses/by/4.0), which permits unrestricted use, distribution, and reproduction in any medium, provided the original work is properly credited. 


\section{Introduction}

Q everal clinical studies demonstrated improved metabolic control in people with type 2 diabetes (T2D) using preprandial supplementary or complementary multiple daily injections (MDI) therapy. ${ }^{1-8} \mathrm{~A}$ less physiological approach that appears to be effective in reducing HbAlc is titration with a single dose of long-lasting insulin or a combined basalbolus concept. ${ }^{9,10}$ It is now well established that continuous subcutaneous insulin infusion (CSII) therapy can further decrease HbA1c concentrations when compared to MDI. ${ }^{1-16}$ However, the primary objective in these studies was to reduce HbAlc by adjusting the daily insulin dose, with less attention paid to other parameters. In contrast to these compelling works, there were randomized trials of CSII versus MDI, which reported no advantages regarding the CSII therapy. ${ }^{17,18}$ In addition, there have been nonrandomized studies with positive results with CSII therapy. ${ }^{19-21}$

Taking into consideration potential harmful effects of hyperinsulinemia in insulin-resistant diabetes patients, ${ }^{22-26}$ the following study aimed to not only improve glycemia, but also evaluate other relevant metabolic indices. Specifically, glucose control, total daily insulin dose (TDD), body mass (BM), insulin resistance, blood pressure (BP), serum triacylglycerols (TAG), low-density lipoprotein (LDL), high-density lipoprotein (HDL), and diabetes treatment satisfaction were examined at 6 and 12 months post-CSII-start in patients with T2D.

\section{Methods}

\section{Study design}

This prospective single-center, randomized study recruited 36 insulin-resistant, C-peptide-positive, glutamic acid decarboxylase antibodies (GAD Ab)-negative, and CSII-naive patients with T2D (eight screen failures). Insulin resistance was empirically defined as a required insulin dose between 0.5 and $1.8 \mathrm{U} / \mathrm{kg}$ of BM per day. These patients who were on insulin analog-based MDI therapy and metformin were recommended from eight regional diabetes departments. Exclusion criteria included active malignancy; acute cardiovascular disorders; acute renal failure; treatment with sulphonylurea, and/or corticosteroids, and/or incretin analogs; pregnancy; and/or poor compliance. Informed consent approved by the local Ethics Committee was obtained from all patients. After enrollment, 28 patients were required to undergo a 2-month run-in period. Insulin dosing was optimized on MDI with insulin analogs and metformin dose was increased to $3000 \mathrm{mg} /$ day.

Following the run-in period, patients were randomized into two groups: a CSII arm or an MDI continuation arm. After 6 months, patients receiving MDI therapy had the option to cross over to CSII therapy: both arms were followed up during 6 additional months, making a total study period of 12 months. CSII was performed using MiniMed ${ }^{\mathrm{TM}} \mathrm{Veo}^{\mathrm{TM}}$ insulin pumps and respective consumables delivering insulin aspart. Before the start of CSII therapy, education on insulin pump therapy was carried out by trained professionals over approximately five sessions. There were 10 scheduled visits in each arm. At Visit 1, patients were randomized into the CSII or MDI arm. At 3 months (Visit 4 or 9), the TDD was incrementally increased in steps if no HbA1c improvements, compared to baseline, were observed.

Cross over from the MDI to CSII arm occurred at 6 months (Visit 5), and a final visit (Visit 10) occurred at 12 months. In both arms, at the CSII start (Visit 1 or Visit 5, respectively), the TDD was reduced by $10 \%-50 \%$ in order not to exceed $80 \mathrm{U} /$ day, without considering the actual HbA1c level.

\section{Self-monitoring and laboratory investigations}

The mean frequency of self-monitoring on a personal glucose meter (CONTOUR ${ }^{\circledR}$ LINK; Ascensia Diabetes Care, Parsippany, NJ) varied in both arms between 3.4 and 5.4 measurements per day.

In addition, glycemia was evaluated with continuous glucose monitoring (CGM) using the Medtronic iPro ${ }^{\mathrm{TM}}$ Professional CGM system, in three blinded 6-day periods (baseline, end of the study phase, end of the continuation phase). Sensors were inserted before Visit 1, Visit 5, and Visit 10.

Laboratory investigations were performed at Covance Laboratories (Switzerland) in which HbA1c was analyzed using a Diabetes Control and Complications-standard assay and given in National Glycohemoglobin Standardization Program (NGSP) units [\%] based on NGSP. To convert these NGSP values (reference range $4.2 \%-6.0 \%$ ) to the recent International Federation of Clinical Chemistry (IFCC) values (reference range $22-42 \mathrm{mmol} / \mathrm{mol}$ ), the following equation was used: IFCC HbA1c $(\mathrm{mmol} / \mathrm{mol})=(\mathrm{NGSP} \mathrm{HbA} 1 \mathrm{c}[\%]-$ 2.15)/0.0915 and rounded (no decimal points).

\section{Statistical evaluation}

The primary efficacy endpoint was the reduction in $\mathrm{HbA1c}$ from baseline to 6 months, which was analyzed with a twosided, two-sample, $t$-test including available measurements. After the initial 6 months of the study phase, patients continued an additional 6 months of CSII therapy. Data at the 12-month visit were pooled to assess 1-year change from baseline using a paired $t$-test. Descriptive statistics for continuous variables included mean, standard deviation, and $95 \%$ confidence interval (CI) limits. All $P$-values were two-sided, and those below 0.05 were considered statistically significant. In addition, the Diabetes Treatment Satisfaction Questionnaire (DTSQ) scores $^{27}$ for the status version (DTSQs) and the change version (DTSQc) were analyzed to look at changes in satisfaction over time: from screening and baseline (i.e., randomization) to 6 months of therapy (Visit 5) and 12 months of therapy (Visit 10). The DTSQc was collected only at Visit 5 and Visit 10.

\section{Results}

\section{Run-in period and randomization}

Following the run-in period, 23 patients (70\% male) were randomized into two groups: a CSII arm $(n=11)$ or an MDI continuation arm $(n=12)$. These patients had persistent $\mathrm{HbA} 1 \mathrm{c} \geq 8 \%$ [64 mmol $/ \mathrm{mol}]$, mean \pm standard deviation age of $57.2 \pm 8.0$ years, body mass index (BMI) of $36.2 \pm 7.0 \mathrm{~kg} / \mathrm{m}^{2}$, $\mathrm{BM}$ of $106.9 \pm 18.3 \mathrm{~kg}$, diabetes duration of $13.3 \pm 4.7$ years, and $\mathrm{HbA} 1 \mathrm{c}$ of $9.5 \% \pm 0.96 \%[80 \mathrm{mmol} / \mathrm{mol}])$. The other remaining 5 of 28 patients $(18 \%)$ were not randomized due to $\mathrm{HbA} 1 \mathrm{c}<8 \%$ [64 mmol $/ \mathrm{mol}]$ at the end of the run-in period. After 6 months, all patients from the MDI arm (except one) crossed over to CSII therapy, and all were followed up for an additional 6 months. In total, 11 completed 12 months of CSII (CSII/CSII arm) and 11 completed 6 months of CSII, after the initial 6 months of MDI (MDI/CSII arm). 


\section{Follow-up visits}

Patients assigned to the CSII arm achieved a significant mean $\mathrm{HbA} 1 \mathrm{c}$ reduction of $0.9 \% \pm 1.1 \% \quad[10 \pm 12 \mathrm{mmol} / \mathrm{mol}] \quad(95 \%$ $\mathrm{CI}=-1.6[-17],-0.1[-1] ; P=0.0312)$, while reducing their TDD by $29.8 \pm 28.41 \mathrm{U} / \mathrm{d}$ ( $33 \%$ of baseline $92.1 \pm 20.35 \mathrm{U} / \mathrm{d})$, achieving a BMI reduction of $-0.3 \pm 1.94 \mathrm{~kg} / \mathrm{m}^{2}(95 \% \mathrm{CI}=-1.61$, $0.99)\left(0.86 \%\right.$ of baseline $\left.36.2 \pm 4.25 \mathrm{~kg} / \mathrm{m}^{2}\right)$, and a BM reduction of $-0.78 \pm 5.61 \mathrm{~kg}(95 \% \mathrm{CI}=-4.55,2.99)(0.74 \%$ of baseline $104.8 \pm 16.15 \mathrm{~kg})$.
Patients on MDI demonstrated a nonsignificant $\mathrm{HbA} 1 \mathrm{c}$ reduction of $0.3 \%$ [ $3 \mathrm{mmol} / \mathrm{mol}](95 \% \mathrm{CI}=-0.8$ [-9], 0.1 [1]) with a TDD reduction of $0.4 \mathrm{U} / \mathrm{d}$ from baseline $(99.0 \pm$ $25.25 \mathrm{U} / \mathrm{d})$, a BMI reduction of $-0.31 \pm 0.70 \mathrm{~kg} / \mathrm{m}^{2}(95 \%$ $\mathrm{CI}=-0.78,0.16)\left(0.9 \%\right.$ of baseline $\left.36.2 \pm 9.07 \mathrm{~kg} / \mathrm{m}^{2}\right)$, and a $\mathrm{BM}$ reduction of $-1.0 \pm 2.03 \mathrm{~kg}(95 \% \mathrm{CI}=-2.36,0.36)$ $(0.91 \%$ of baseline $108.9 \pm 20.55 \mathrm{~kg})$. The between-group difference in 6-month $\mathrm{HbA} 1 \mathrm{c}$ reduction was $-0.53 \% \pm 0.9 \%$ $[1 \pm 10 \mathrm{mmol} / \mathrm{mol}]$ in favor of the CSII arm, but it was not significant $(P=0.20)$.
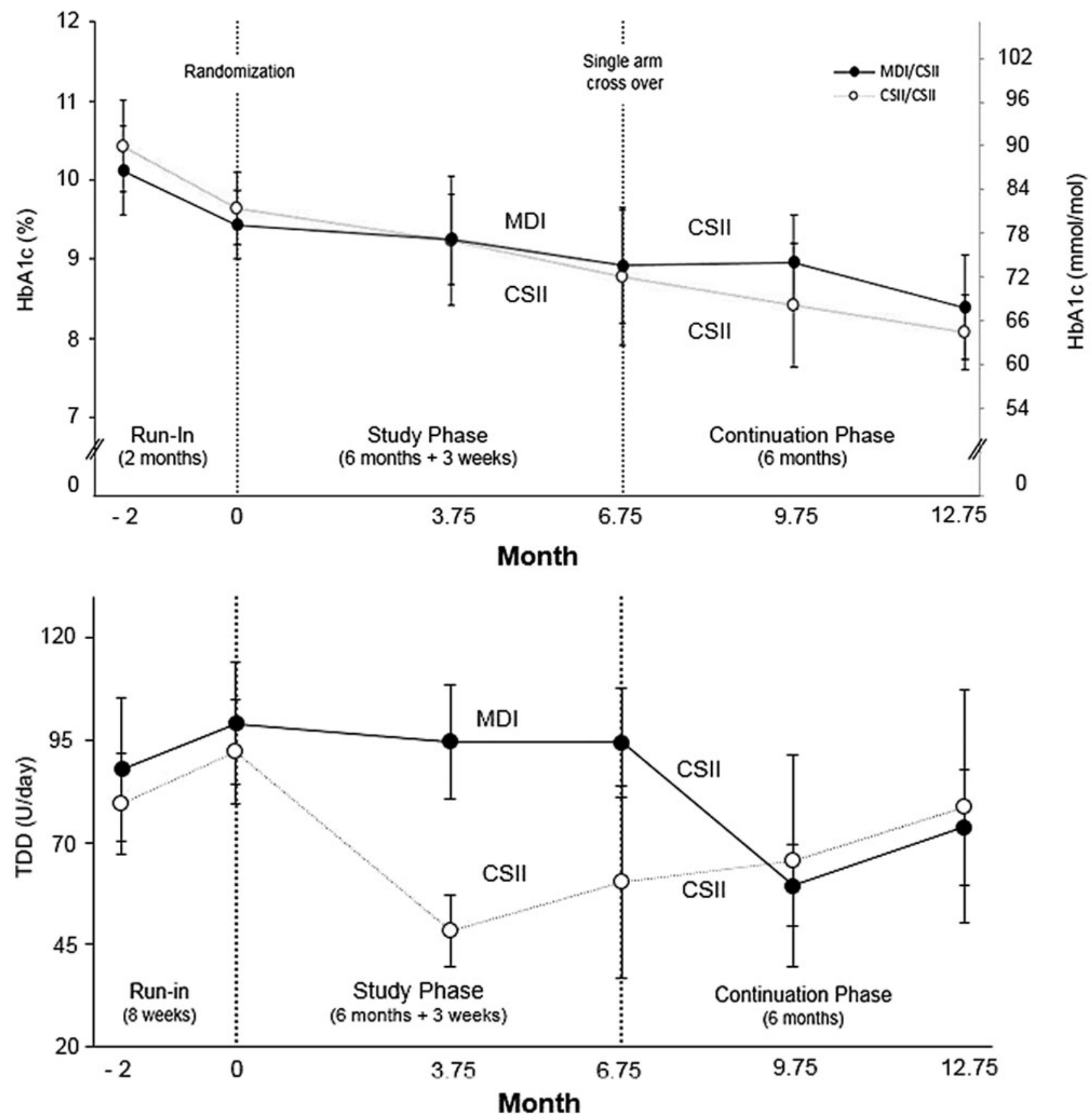

FIG. 1. HbA1c and insulin total daily dose during the course of the study. HbA1c and TDD during the course of the study. The HbA1c (top) and TDD (bottom) in the MDI/CSII arm $(N=11$, closed symbols) and the CSII/CSII arm ( $N=11$, open symbols) are shown. Symbols and bars show the mean and 95\% CI, respectively. CI, confidence interval; CSII, continuous subcutaneous insulin infusion; MDI, multiple daily injections; TDD, total daily insulin dose. 
At 12 months, data from both arms $(N=11$ continuing CSII from the randomization visit for 12 months, and $N=11$ following crossover from MDI to CSII at Visit 5 for 6 months) demonstrated a mean $1.2 \% \pm 0.87 \%[13 \pm 10 \mathrm{mmol} /$ mol] HbA1c reduction from baseline $(9.5 \%$ [80 mmol $/ \mathrm{mol}])$ $(P<0.0001)$ with $41 \%$ of patients achieving $\mathrm{HbA} 1 \mathrm{c}<8 \%$ (64 mmol/mol); a mean TDD reduction from baseline $(95.7 \pm 22.75 \mathrm{U} / \mathrm{d})$ of $13.7 \pm 29.7 \mathrm{U} / \mathrm{d}$ (i.e., $0.14 \mathrm{U} / \mathrm{d} / \mathrm{kg}$ of $\mathrm{BM})$. No significant change versus baseline was noted in terms of BM $(107.0 \mathrm{~kg}$ vs. $107.1 \mathrm{~kg})$. In addition, and relative to baseline, results showed systolic BP of 140.7 torr versus 139.6 torr; diastolic BP of 83.3 torr versus 78.3 torr; $\mathrm{HDL}$ of $1.2 \mathrm{mmol} / \mathrm{L}$ versus $1.2 \mathrm{mmol} / \mathrm{L} ; \mathrm{LDL}$ of $2.2 \mathrm{mmol} / \mathrm{L}$ versus $2.3 \mathrm{mmol} / \mathrm{L}$; and TAG of $2.8 \mathrm{mmol} / \mathrm{L}$ versus $2.2 \mathrm{mmol} / \mathrm{L}$; with no ketoacidosis or severe hypoglycemia occurring in either arm.

The course of HbA1c and TDD in the individual study arms are displayed in Figure 1. The mean time spent per day in hypoglycemia $(\leq 70 \mathrm{mg} / \mathrm{dL}[\leq 3.9 \mathrm{mmol} / \mathrm{L}])$ at baseline (Visit 1), Visit 5, and Visit 10 is also shown in Figure 2. Compared to baseline, there was no significant change in the percentage of time spent in hypoglycemia at the 6-month visit (MDI/CSII 95\% CI $=[-2.5 \%, 1.5 \%], \mathrm{CSII} / \mathrm{CSII} 95 \%$ $\mathrm{CI}=[-2.5 \%, 3.5 \%])$. Likewise, no significant change was observed when comparing hypoglycemia exposure between baseline and the 12-month visit. Compared to baseline, there was no significant reduction in the mean amplitude of glycemic excursions for the MDI/CSII arm (-3.0 [33.6] and -8.7 [29.0]) or the CSII/CSII arm (-12.9 [20.6] and -15.1 [27.2]) at the 6-month and 12-month visits, respectively. The standard deviation of sensor glucose values (i.e., variability) decreased at the 6- and 12-month visits for the CSII/CSII arm
$(-4.7 \pm 7.9 \mathrm{mg} / \mathrm{dL}[-0.26 \pm 0.44 \mathrm{mmol} / \mathrm{L}]$ and $-4.8 \pm 7.6 \mathrm{mg} / \mathrm{dL}$ $[0.27 \pm 0.42 \mathrm{mmol} / \mathrm{L}]$, respectively), but was not statistically significant. Compared to baseline, neither the increased standard deviation of sensor glucose values for the MDI/ CSII arm at 6 months $(5.8 \pm 2.0 \mathrm{mg} / \mathrm{dL}[0.32 \pm 0.11 \mathrm{mmol} / \mathrm{L}])$, nor the decreased standard deviation of sensor glucose at 12 months $(-3.8 \pm 9.4 \mathrm{mg} / \mathrm{dL}[-0.21 \pm 0.52 \mathrm{mmol} / \mathrm{L}])$ was significant.

\section{DTSQ scores over time}

Tables 1 and 2 show the results of DTSQs and DTSQc questionnaires, respectively, during the study and changes in scores over time, for both the CSII/CSII and MDI/CSII arms. Relative to baseline, there was a small increase in the DTSQs for the CSII/CSII arm at 6 months that was minimally increased by the end of the study. For the MDI/CSII arm, the DTSQs were minimally reduced at 6 months relative to baseline, but comparable to that of the CSII/CSII arm by 12 months. Patients within both arms reported similar DTSQc scores at 6 and 12 months, with a comparable increase in change between the visits.

\section{Adverse events}

There was a total of 31 various adverse events registered in 8 of 22 patients when using CSII during the study and continuation phase. Only one of the events (i.e., weakness, slight headache, sweating, and tremor followed by short unconsciousness with spontaneous recovery), which appeared at home without medical assistance or glycemia monitoring, was deemed related to diabetes.

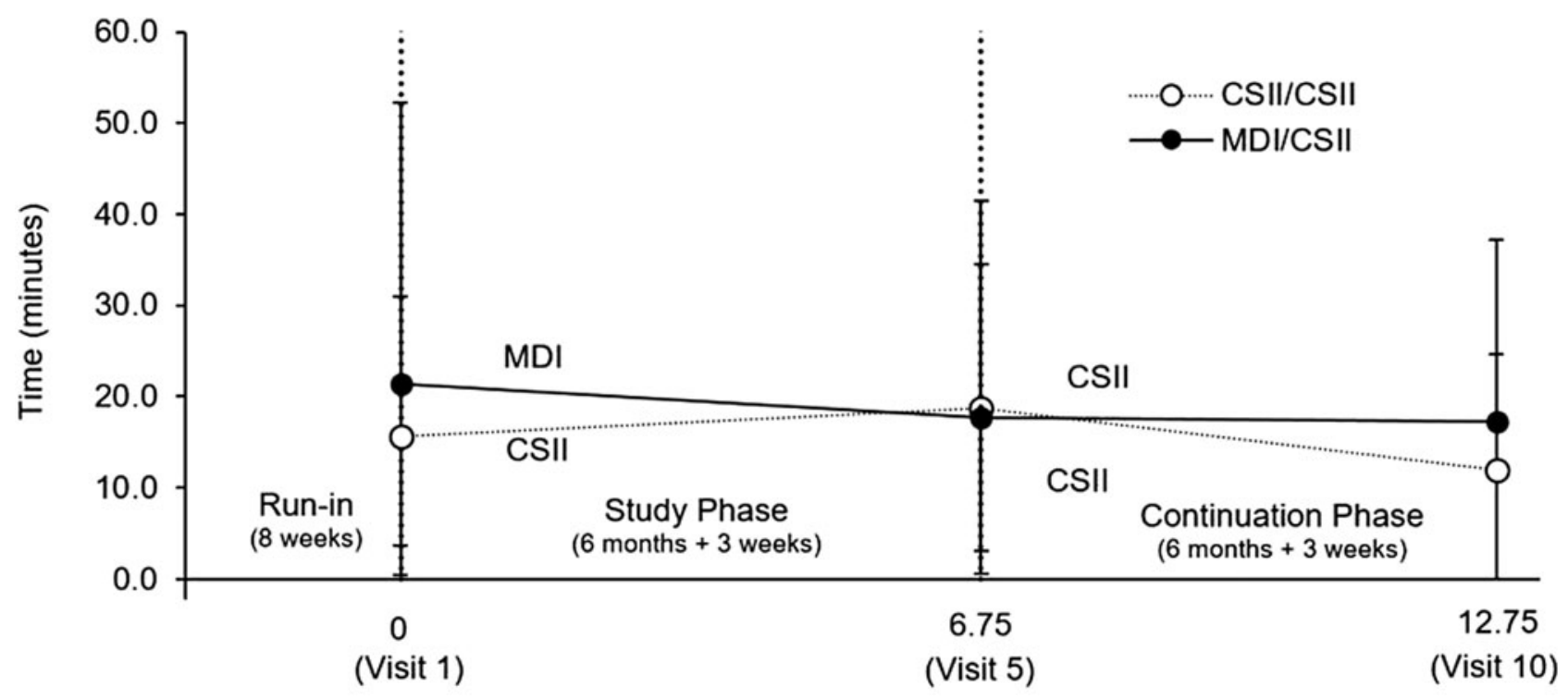

Month

FIG. 2. Mean daily hypoglycemia exposure during the study. The mean time (in minutes) of hypoglycemia $(\leq 70 \mathrm{mg} / \mathrm{dL}$, $\leq 3.9 \mathrm{mmol} / \mathrm{L})$ exposure per day is shown for the MDI/CSII arm $(N=11$, closed symbols $)$ and the CSII/CSII arm $(N=10$, open symbols) at baseline (Visit 1), 6 months (Visit 5), and 12 months (Visit 10, end of study). While hypoglycemia exposure was reduced in the MDI arm that transitioned to CSII therapy by end of study (Visit 10), this was NS when compared to baseline. For the CSII/CSII arm, hypoglycemia exposure was increased from Visit 5 to end of study (NS, compared to baseline). Symbols and bars show the mean and 95\% CI, respectively. NS, not significant. 
Table 1. Change in the Diabetes Treatment Satisfaction Questionnaire (Status) Score

\begin{tabular}{|c|c|c|c|c|c|c|c|c|}
\hline \multirow{2}{*}{$\begin{array}{l}\text { Treatment } \\
\text { arm }\end{array}$} & \multirow[b]{2}{*}{ Category } & \multicolumn{2}{|c|}{ Run-in } & \multirow{2}{*}{$\begin{array}{c}\text { Study phase } \\
6 \text { months } \\
\text { (Visit 5) }\end{array}$} & \multirow{2}{*}{$\begin{array}{l}6 \text { months } \\
\text { change from } \\
\text { baseline }\end{array}$} & \multirow{2}{*}{$\begin{array}{l}\text { Continuation } \\
\text { phase } 12 \\
\text { months } \\
\text { (Visit 10) }\end{array}$} & \multirow{2}{*}{$\begin{array}{l}12 \text { months } \\
\text { change } \\
\text { from } \\
6 \text { months }\end{array}$} & \multirow{2}{*}{$\begin{array}{l}12 \text { months } \\
\text { change } \\
\text { from } \\
\text { baseline }\end{array}$} \\
\hline & & Screening & Baseline & & & & & \\
\hline \multirow{6}{*}{ CSII/CSII } & Number of subjects & 11 & 11 & 11 & 11 & 11 & 11 & 11 \\
\hline & Mean (SD) & $25.9(5.11)$ & $30.4(3.50)$ & $31.6(2.66$ & $1.3(3.55)$ & $32.9(3.05)$ & $1.3(1.74)$ & $2.6(3.2$ \\
\hline & Median & 26.0 & 30.0 & 31.0 & 0.0 & 34.0 & 1.0 & 1.0 \\
\hline & Minimum, maximum & $18.0,35.0$ & $25.0,36.0$ & & & & $-1.0,4.0$ & $-1.0,9.0$ \\
\hline & $95 \%$ confidence interval & $22.5,29.3$ & $28.0,32.7$ & $29.9,33.4$ & $-1.1,3.7$ & $30.9,35.0$ & $0.1,2.4$ & $0.4,4.7$ \\
\hline & $\begin{array}{l}\text { Interquartile range } \\
(25 \%, 75 \%)\end{array}$ & $21.0,29.0$ & $27.0,34.0$ & $30.0,34.0$ & $-2.0,3.0$ & $31.0,36.0$ & $0.0,3.0$ & $0.0,5.0$ \\
\hline \multirow{5}{*}{ MDI/CSII } & $\begin{array}{l}\text { Number of subjects } \\
\text { Mean (SD) }\end{array}$ & $\begin{array}{c}12 \\
24.8(5.18\end{array}$ & $\begin{array}{c}12 \\
30.3(4.99)\end{array}$ & 11 & $\begin{array}{c}11 \\
-0.5(4.59)\end{array}$ & $\begin{array}{c}11 \\
32.9(3.83)\end{array}$ & $\begin{array}{c}11 \\
2.8(4.92)\end{array}$ & $\begin{array}{c}11 \\
2.4(2.8\end{array}$ \\
\hline & Median & $\begin{array}{c}24.0 \\
24.0\end{array}$ & $\begin{array}{c}31.0 \\
31.0\end{array}$ & $\begin{array}{l}33.1(J .00) \\
33.0\end{array}$ & & & & \\
\hline & $\mathrm{Mi}$ & $18.0,34.0$ & $19.0,36.0$ & $19.0,35$ & $-10.0,7.0$ & & $-3.0,12.0$ & $-2.0,8$. \\
\hline & $95 \%$ confidence interval & $21.5,28.1$ & $27.1,33.4$ & $26.2,34$ & $-3.5,2.6$ & $30.3,3$ & $-0.5,6.1$ & $0.5,4.2$ \\
\hline & $\begin{array}{l}\text { Interquartile range } \\
(25 \%, 75 \%)\end{array}$ & $21.0,29.0$ & $28.5,34.0$ & $26.0,34.0$ & $-4.0,2.0$ & $31.0,36.0$ & $-2.0,7.0$ & $0.0,4.0$ \\
\hline
\end{tabular}

CSII, continuous subcutaneous insulin infusion; MDI, multiple daily injections; SD, standard deviation.

\section{Discussion}

The purpose of this study was to improve the HbA1c and $\mathrm{BM}$ in obese insulin-resistant T2D patients using the smallest TDD of rapid-acting insulin analog and maximum dose of metformin. The diagnosis of T2D was based on clinical assessment of the referring diabetes specialist supported by prestudy findings of normal or increased C-peptide concentrations and GAD $\mathrm{Ab}$ within the reference range. Insulin therapy in T2D (previously described as noninsulin dependent diabetes) relates to very old references. ${ }^{1-9}$ Some authors preferred the physiological approach with MDI and complemented the missing peak of postprandial endogenous insulin secretion (using small subcutaneous doses of shortacting insulin or insulin analog before each meal, adopted according to intensive self-monitoring). ${ }^{1-8}$ Other authors recommended a more comfortable regimen using once-daily injection of long-lasting insulin titrated according to a single value of fasting glycemia. The latter approach often resulted in increased BM and increased frequency of hypoglycemia. ${ }^{9}$

Regarding CSII therapy in patients with T2D; between 2003 and 2005, there were two randomized trials of CSII versus MDI, which demonstrated no advantages with CSII therapy. In contrast, several nonrandomized pilot studies, between 2010 and 2011, reported optimistic results. ${ }^{11,12,19-21}$ As late as 2016, the outcomes of the randomized controlled OpT2mise study ${ }^{13-16}$ have demonstrated significant superiority of CSII therapy over MDI therapy with HbA1c as primary endpoint.

In this study, over the course of 3 months with CSII therapy, the TDD in the CSII/CSII arm was reduced from $92.1 \mathrm{U} / \mathrm{d}$ at baseline to $48.5 \mathrm{U} / \mathrm{d}$ by Visit 4 . In contrast, the TDD in the MDI/ CSII arm was reduced from $94.3 \mathrm{U} / \mathrm{d}$ at Visit 5 to $59.4 \mathrm{U} / \mathrm{d}$ by Visit 9 (i.e., as late as after crossing over to CSII) and showed no significant increase of HbA1c. Thus, CSII was more effective than MDI (perhaps due to the more physiological mode of basal

Table 2. Change in the Diabetes Treatment Satisfaction Questionnaire (Change) Score

\begin{tabular}{|c|c|c|c|c|}
\hline Treatment arm & Category & $\begin{array}{l}\text { Study phase } \\
6 \text { months } \\
\text { (Visit 5) }\end{array}$ & $\begin{array}{c}\text { Continuation } \\
\text { phase } 12 \text { months } \\
\text { (Visit 10) }\end{array}$ & $\begin{array}{l}12 \text { months } \\
\text { change from } \\
6 \text { months }\end{array}$ \\
\hline CSII/CSII & $\begin{array}{l}\text { Number of subjects } \\
\text { Mean (SD) } \\
\text { Median } \\
\text { Minimum, maximum } \\
\text { 95\% confidence interval } \\
\text { Interquartile range }(25 \%, 75 \%)\end{array}$ & $\begin{array}{c}11 \\
13.1(3.53) \\
12.0 \\
6.0,18.0 \\
10.7,15.5 \\
11.0,16.0\end{array}$ & $\begin{array}{c}11 \\
16.1(2.26) \\
17.0 \\
12.0,18.0 \\
14.6,17.6 \\
13.0,18.0\end{array}$ & $\begin{array}{c}11 \\
3.0(3.63) \\
2.0 \\
-1.0,11.0 \\
0.6,5.4 \\
0.0,5.0\end{array}$ \\
\hline MDI/CSII & $\begin{array}{l}\text { Number of subjects } \\
\text { Mean (SD) } \\
\text { Median } \\
\text { Minimum, maximum } \\
\text { 95\% confidence interval } \\
\text { Interquartile range }(25 \%, 75 \%)\end{array}$ & $\begin{array}{c}11 \\
13.6(5.05) \\
16.0 \\
1.0,18.0 \\
10.2,17.0 \\
11.0,17.0\end{array}$ & $\begin{array}{c}11 \\
16.3(1.95) \\
17.0 \\
13.0,18.0 \\
15.0,17.6 \\
14.0,18.0\end{array}$ & $\begin{array}{c}11 \\
2.6(4.25) \\
1.0 \\
-2.0,13.0 \\
-0.2,5.5 \\
0.0,3.0\end{array}$ \\
\hline
\end{tabular}

The Diabetes Treatment Satisfaction Questionnaire was only collected at Visit 5 and Visit 10. 
insulin administration with insulin pump infusion therapy). When the TDD was increased in the CSII/CSII arm from $48.5 \mathrm{U} / \mathrm{d}$ (Visit 4) to $78.8 \mathrm{U} / \mathrm{d}$ (Visit 10), or in the MDI/CSII arm from $59.4 \mathrm{U} / \mathrm{d}$ (Visit 9) to $73.7 \mathrm{U} / \mathrm{d}$ (Visit 10), there was a significant $\mathrm{HbA} 1 \mathrm{c}$ reduction in the CSII/CSII arm from $9.2 \%$ (Visit 4) to $8.1 \%$ (Visit 10$)(77-65 \mathrm{mmol} / \mathrm{mol})$ and in the MDI/CSII arm from $9.0 \%$ (Visit 9) to $8.4 \%$ (Visit 10) (75-68 mmol/mol), respectively (Fig. 1), without any significant change in the frequency of hypoglycemia (Fig. 2). Our findings correspond to the meta-analysis of randomized trials. ${ }^{28}$ Thus, reducing a previously high TDD at CSII start (without considering actual glycemia or HbA1c value) appears to be worthy of further investigation. In addition, despite significant reduction of $\mathrm{HbA} 1 \mathrm{c}$, it is necessary to bear in mind that only $41 \%$ of 22 patients using CSII achieved HbA1c $<8 \%$ (64 mmol/mol) and no significant change versus baseline was noted in terms of BM $(107.0 \mathrm{~kg}$ vs. $107.1 \mathrm{~kg})$. Therefore, the potential combination of CSII with recently appearing incretins and/or gliflozins may also become a topic for future research. ${ }^{29,30}$

\section{Conclusion}

The use of CSII therapy in individuals with insulinresistant T2D is both safe and effective for improving glucose control and reducing insulin usage, although without a sustainable reduction in $\mathrm{BM}, \mathrm{BP}$, or lipid profile. While an optimum metabolic balance in most of the patients was not reached, treatment adherence and satisfaction were excellent. All subjects decided to continue using CSII therapy.

\section{Acknowledgments}

Parts of this study were presented at the 75th Scientific Sessions of the American Diabetes Association in Boston, June 9th13th, 2015 and at the 42nd National Congress of the Romanian Society of Diabetes, Nutrition and Metabolic Diseases, Brasov, May 25th-28th, 2016. R.C., a principal investigator of the study, received research support and compensation for conducting the study. S.R., J.C., S.W.L., O.C., X.N., and T.L.C. were involved in data analysis and/or critical review of the article. With thanks to Toni Cordero (Medtronic) and to Blanka Doubravova, Emilia Durajkova, Pavla Indreiova, Michaela Nadvornikova, Jana Polcerova, Ludmila Smazakova, Ludmila Smekalova, Alena Smrckova, Jana Valentova, and Jana Ferancova (Moravsky Beroun), for ongoing support. This study was funded by Medtronic. ClinicalTrials.gov ID: NCT01182493.

\section{Author Disclosure Statement}

S.R., J.C., S.W.L., O.C., X.N., and T.L.C. are employees of Medtronic.

\section{References}

1. Bruns W, Jutzi E, Staritz B, et al.: Zur Behandlung von TypII-Diabetikern mit Sulphonylharnstoff-SekundärversagenKombinationstherapie mit Glibenclamid und Insulin. 3. Komplementäre Insulintherapie in kleinen Dosen (Treatment of type 2 diabetics (non-insulin-dependent) for sulphonylurea secondary failure-combined therapy, using glibenclamid and insulin. 3. Complementary small insulin boluses.) Z Klin Med (DDR) 1990;45:983-986.

2. Chlup R, Vaverková H, Bartek J: Complementary insulin therapy improves blood glucose and serum lipids parame- ters in type 2 (non-insulin-dependent) diabetic patients. I. Effects on blood glucose control. Exp Clin Endocrinol Diabetes 1997;105 (Suppl. 2):70-73.

3. Vaverková H, Chlup R, Ficker L, et al.: Complementary insulin therapy improves blood glucose and serum lipids parameters in type 2 (non-insulin-dependent) diabetic patients. II. Effects on serum lipids, lipoproteins and apoproteins. Exp Clin Endocrinol Diabetes 1997;105 (Suppl. 2):74-77.

4. Berger M, Jörgens V, Mühlhauser I: Rationale for the use of insulin therapy alone as the pharmacological treatment of type 2 diabetes. Diabetes Care 1999;22(Suppl 3):C71C75.

5. Ohkubo Y, Kishikawa H, Araki E, et al.: Intensive insulin therapy prevents the progressions of diabetic microvascular complications in Japanese patients with non-insulin-dependent diabetes mellitus: a randomized prospective 6-year study. Diabetes Res Clin Pract 2000;28:103-117.

6. Lundershausen R, Kaiser M, Haeuser C, et al.: Effectiveness of prandial insulin therapy for patients with Type 2 diabetes - clinical results of PHAZIT. Diabetologia 2004; 47:A264 (Abstract).

7. Bruns W, Fiedler H, Altmann B, et al.: Insulintherapie bei Typ 2-Diabetes-Pathophysiologisch Begründete Therapie mit Insulin uter Besonderer Berücksichtigung der Insulinresistenz (Insulin Treatment in Type 2 Diabetes-Pathophysiology-Based Insulin Treatment with Particular Consideration of Insulin Resistance). 1. Auflage; UNI-MED Verlag AG, Bremen, 2004.

8. Bretzel RG: Intensive insulin regimens: evidence for benefit. Int J Obes 2004;Suppl 2:58-513.

9. Yki-Järvinen H, Kauppila M, Kujansuu E, et al.: Comparison of insulin regimens in patients with non-insulindependent diabetes mellitus. N Engl J Med 1992;327:14261433.

10. Inzucchi SE, Bergenstal RM, Buse JB, et al:: American Diabetes Asssociation (ADA); European Association for the Study of Diabetes (EASD): management of hyperglycaemia in type 2 diabetes: a patient- centered approach: position statement of the American Diabetes Association (ADA) and the European Association for the Study of Diabetes (EASD). Diabetes Care 2012;35:1364-1379.

11. Reznik Y, Morera J, Rod A, et al.: Efficacy of continuous subcutaneous insulin infusion in type 2 diabetes mellitus: a survey on a cohort of 102 patients with prolonged followup. Diabetes Technol Ther 2010;12:931-936.

12. Chlup R, Peterson K, Zapletalová J, et al.: Impact of continuous subcutanous insulin infusion on metabolic parameters and well-being in persons with type 2 diabetes. Diabetes 2010;59(Suppl 1):550 (Abstract).

13. Aronson R, Cohen O, Conget I, et al; for the OpT2mise Study Group: OpT2mise: a randomized controlled trial to compare insulin pump therapy with multiple daily injections in the treatment of type 2 diabetes-research design and methods. Diabetes Technol Ther 2014;16:414-420.

14. Reznik Y, Cohen O, Aronson R, et al.: Insulin pump treatment compared with multiple daily injections for treatment of type 2 diabetes (OpT2mise): a randomised open-label controlled trial. Lancet 2014;384:1265-1272.

15. Conget I, Castaneda J, Petrovski G, et al; for the OpT2MISE Study Group: The impact of insulin pump therapy on glycemic profiles in patients with type 2 diabetes: data from the OpT2mise study. Diabetes Technol Ther 2016;18:22-28.

16. Aronson R, Reznik Y, Conget I, et al.; for the OpT2mise Study Group: Sustained efficacy of insulin pump therapy 
compared with multiple injections in type 2 diabetes: 12-month data from the OpT2mise randomised trial. Diabetes Obes Metab 2016;18(5):500-507.

17. Herman WH, Ilag LL, Johnson SL, et al.: Clinical trial of continuous subcutaneous insulin infusion versus multiple daily injections in older adults with type 2 diabetes. Diabetes Care 2005;28:1568-1573.

18. Raskin P, Bode BW, Marks JB, et al.: Continuous subcutaneous insulin infusion and multiple daily injection therapy are equally effective in type 2 diabetes - a randomized parallel-group, 24 week study. Diabetes Care 2003;26: 2598-2603.

19. Frias JP, Bode BW, Bailey TS, et al.: A 16-week open label, multicenter pilot study assessing insulin pump therapy in patients with type 2 diabetes suboptimally controlled with multiple daily injections. J Diabetes Sci Technol 2011; 5:887-893.

20. Anhalt H, Rodbard D, BaileyT, et al. Continuous subcutaneous insulin infusion (CSII) in type 2 diabetes: reductions in HbA1c, mean glucose and variability. Diabetologia 2011;54(Suppl 1):S400-S400 (Abstract).

21. Peyrot M, Rubin RR, Chen X, Frias JP: Associations between improved glucose control and patient-reported outcomes after initiation of insulin pump therapy in patients with type 2 diabetes mellitus. Diabetes Technol Ther 2011; 13:471-476.

22. Stout RW: Overview of the association between insulin and atherosclerosis. Metabolism 1985; 34/12 (Suppl1):7-12.

23. Muis J, Bots L, Grobbee E, et al.: Insulin treatment and cardiovascular disease; friend or foe? A point of view. Diabet Med 2005;22:118-126.

24. Reige B, Assendelft J, Dekker M, et al.: Insulin and risk of cardiovascular disease. Circulation 1998;97:996-1001.

25. Uusitupa I, Niskanen K, Siitonen O, et al.: 5-year incidence of atherosclerotic vascular disease in relation to general risk factors, insulin level, and abnormalities in lipoprotein composition in non-insulin-dependent diabetic and nondiabetic subjects. Circulation 1990;82:27-36.

26. Monnier L, Hanefeld M, Schnell O, et al.: Insulin and atherosclerosis: how are they related?. Diabetes Metab 2013; 39(2):111-117.

27. Bradley C: The Diabetes Treatment Satisfaction Questionnaire: DTSQ. In: Bradley C, ed. Handbook of Psychology and Diabetes: A Guide to Psychological Measurement in Diabetes Research and Practice. Chur, Switzerland; Harwood Academic Publishers, 1994, pp. 111-133.

28. Pickup JC, Reznik Y, Sutton AJ: Glycemic control during continuous subcutaneous insulin infusion versus multiple daily insulin injections in type 2 diabetes: individual patient data meta-analysis and meta-regression of randomized controlled trials. Diabetes Care 2017;40:715-722.

29. Chlup R, Zapletalova J, Ramik Z, et al.: Impact of dapagliflozin on metabolic control in people with type 2 diabetes using insulin pumps. Diabetes 2017;66 (Suppl 1):A297-A298 1119-P (Abstract).

30. Chlup R, Zapletalova J, Cheng TH, et al.: Effects of incretins in people with type 2 diabetes on CSII. Diabetes 2017;66(Suppl 1):A623 2387-PUB (Abstract).

Address correspondence to: Rudolf Chlup, $M D$

Department of Physiology Faculty of Medicine and Dentistry Palacký University Hněvotínská 3 Olomouc 77900 Czech Republic

E-mail: rudolf.chlup@fnol.cz 